\title{
Adeline Mowbray, or, the Bitter Acceptance of Woman's Fate
}

\author{
Aída Díaz Bild \\ University of La Laguna \\ adbild@ull.es
}

\begin{abstract}
Eighteenth-century women writers believed that the novel was the best vehicle to educate women and offer them a true picture of their lives and "wrongs". Adelina Mowbray is the result of Opie's desire to fulfil this important task. Opie does not try to offer her female readers alternatives to their present predicament or an idealized future, but makes them aware of the fact that the only ones who get victimized in a patriarchal system are always the powerless, that is to say, women. She gives us a dark image of the vulnerability of married women and points out not only how uncommon the ideal of companionate marriage was in real life, but also the difficulty of finding the appropriate partner for an egalitarian relationship. Lastly, she shows that there is now social forgiveness for those who transgress the established boundaries, which becomes obvious in the attitude of two of the most compassionate and generous characters of the novel, Rachel Pemberton and Emma Douglas, towards Adelina.
\end{abstract}

Amelia Opie was one of the most popular and celebrated authors during the $1800 \mathrm{~s}$ and $1810 \mathrm{~s}$, whose techniques and themes reveal her to be a representative woman novelist of her time. Unfortunately, her achievements were eclipsed by those of Elizabeth Gaskell, George Eliot, Charles Dickens or the Brontës, and for a long time her work remained entirely forgotten. However, in the last years there has been a growing interest to recover and reappraise her novels and poems, trying to establish links between Opie and other late eighteenth- and early nineteenth-century women writers. In contrast to contemporary reviewers who emphasized the conservative and anti-Jacobin message of her novels and tales, most twentieth-century critics have defended the dialogical quality of her work, or, in other words, the way in which Opie appears to endorse the status quo, while criticizing those social institutions, such as 
marriage and patriarchy, that oppress women. ${ }^{1}$ It has been argued that this use of oblique or indirect techniques to explore woman's predicament is the result of Opie's desire to disassociate herself from the revolutionary principles of the $90 \mathrm{~s}$, to which she had been so deeply committed, and thus avoid her reputation being sullied in an age evidently reactionary and conservative. ${ }^{2}$ While it cannot be denied that Opie denounces the abuses of established power, I do not believe that she does it in a cover way in order to protect her image as a "proper lady". If social conventions remain triumphant at the end of her novels, it is not because Opie is eager to satisfy her reader's expectations, but because she is aware of the fact that in the counterrevolutionary period in which she was writing there were no other options for women. This becomes clear in Adeline Mowbray (1805), a novel which, as we shall see, does not try to offer female readers alternatives to their present lot or an idealized future, but merely makes them aware of the fact that they do not exist.

In order to understand Opie's realistic approach to women's lives it is first necessary to examine the socio-political background of her age. By the time Amelia Opie starts writing Adeline Mowbray, the enthusiasm for the French Revolution has long faded away. In the early stages many British liberal thinkers, the so-called Jacobins, believed that the French insurrection could serve as a model for a peaceful reform in England. They were convinced that if the French example was followed, British society would become more liberal and egalitarian. But towards the middle years of the 1790 s the revolutionary excitement declined due to three key events: France was veering towards chaos and terror under Robespierre, many London radical leaders had been arrested for high treason, and there was an increase in patriotic feeling as a result of the Napoleonic invasions. The Jacobins became increasingly unpopular and their work the main target of many novels published at the end of the century, such as Elizabeth Hamilton's Letters of a Hindoo Rajah (1796) and Memoirs of Modern Philosophers (1800), Isaac D'Israeli's Vaurien (1797), Edward Dubois's The Travels of St. Godwin (1800) or Charles Lloyd's Edmund Oliver (1798).

In this reaction against any kind of liberal or revolutionary response, women were especially pointed at thanks to Godwin's publication of Memoirs of the Author of " $A$ Vindication of the Rights of Woman" in 1798, in which he gave all the details about Wollstonecraft's unconventional life: her passion for Fuseli, her love affair with Gilbert Imlay, the birth of her illegitimate child, her two attempts of suicide, her pre-marital relationship with Godwin, etc. As a result, "Wollstonecraftian feminism became synonymous with licentiousness" (Todd, 1989: 215). The Anti-Jacobin Review of 1798 does not hesitate to list her in the index under the word "prostitution" and conservative writer and theologian Reverend Richard Polwhele, author of the famous The Unsex'd Females: A Poem (1798), accuses Wollstonecraft and her followers of having despised the laws of nature and resigned "To Gallic freaks or Gallic Faith" (Polwhele, 1991: 186) He also explains in a note to the poem that Wollstonecraft's death at childbirth is a good reminder of the differences between the two sexes. As a matter of fact, and as Johnson has clearly explained, conservatives were "shocked to realize that if women were indeed educated and permitted to act like 'rational creatures', they might consider themselves entitled, as free agents, to frame their own desires and pursue happiness on their own terms, rather than be content as dutiful daughters or submissive wives." (Johnson, 1990: 15) Thus the end of the eighteenth century was defined 
by a reinforcement of conservatism and anti-feminism and a reaction against any kind of revolutionary reform, especially as far as women's equality was concerned. ${ }^{3}$

Instead, "a renewed model of 'domestic woman' as professionalized custodian of the 'national' conscience, culture and destiny" (Kelly, 1997: 21) was endorsed. In the final years of the age of the Enlightenment the female ideal that the conduct books had helped to construct throughout the century ${ }^{4}$ was firmly reasserted. A virtuous woman had to be defined by her meekness, submission, chastity, modesty, reserve, delicacy, sympathy, gentleness, as well as a unique capacity for self-control and self-knowledge. ${ }^{5}$ Reacting against the reformers and the way in which they challenged the traditional family structure, conservative novels and conduct books preached domesticity, resignation and the duty of female submission and propriety. ${ }^{6}$ A wife's main obligation was to please and content her husband by loving, honouring and obeying him, thus making marital harmony the sole responsibility of women. James Fordyce, whose Sermons to Young Women (1766) together with other conservative conduct books was reprinted at the end of the eighteenth century, expressed this idea clearly:

I am astonished at the folly of many women, who are still reproaching their husbands for leaving them alone, for preferring this or that company to theirs, for treating them with this and the other mark of disregard or indifference; when, to speak the truth, they have themselves in a great measure to blame. Not that I would justify the men in any thing wrong on their part. But had you behaved to them with more respectful observance, and a more equal tenderness; studying their humours, overlooking their mistakes, submitting to their opinions in matters indifferent, passing by little instances of unevenness, caprice, or passion, giving soft answers to hasty words, complaining as seldom as possible, and making it your daily care to relieve their anxieties and prevent their wishes, to enliven the hour of dullness, and call up the ideas of felicity: had you pursued this conduct, I doubt not but you would have maintained and even increased their esteem, so far as to have secured every degree of influence that could conduce to their virtue, or your mutual satisfaction; and your house might at this day have been the abode of domestic bliss. ${ }^{7}$ (In Wollstonecraft, 1993: 177-178)

Conservative texts contributed to establishing a hierarchical structure based on two separate spheres: the domestic or private one, to which women belonged, and the public, which was the domain of men: "Of this kind is the Government of your House, Family, and Children, which since it is the Province allotted to your Sex, and that the discharging it well, will for that reason be expected from you,..." (Savile, 1991:21). Together with the relegation of women to the domestic domain, the end of the eighteenth century, beginning of the nineteenth century witnessed a newer notion of woman's superiority as they began to be celebrated as the refiners of society, whose main function was to elevate man's sentiments and inspire their highest impulses. More reflects this attitude when, on attacking aristocratic values and defending middle-class ones, vindicates the role of women not only as agents of social and moral reform, but also of national survival. ${ }^{8}$ Hamilton expresses a similar idea by stressing that women are the foundation of all social order, since they are responsible for their children's education. She even goes so far as to argue that "National happiness will then be considered to depend on national morals" (Hamilton, 1813: 352) and that the only way to guard these morals from corrupting is by cultivating the intellectual powers of individual 
minds and developing the benevolent affections.

It must be observed that by emphasising women's role as the refiners of society, these conservative writers were echoing and amplifying what thinkers like John Gregory or François de Salignac, whose work was still consulted, had expressed decades before. Thus François de Salignac develops the following argument in Treatise on the Education of Daughters (1687):

Consider, it is women who ruin or uphold families; who regulate the minutiae of domestic affairs; and who consequently decide upon some of the dearest and tenderest points which affect the happiness of Man. They have undoubtedly the strongest influence on the manners, good or bad, of society. A sensible woman, who is industrious and religious, is the very soul of a large establishment, and provides both for its temporal and eternal welfare. Notwithstanding the authority of men in public affairs, it is evident, that they cannot effect any lasting good, without the intervention and support of women.

The world is not a phantom, it is the aggregate of all its families; and who can civilize and govern these with a nicer discrimination than women? (Salignac, 1991: 102-103)

Women were, of course, seduced with these visions of power to civilize and govern the family, but as Gary Kelly has explained in "Revolutionary and Romantic Feminism" "this 'protection'of woman in the subjective, private, familial sphere was in fact relegation. Furthermore, it rationalised the exclusion of women from the spheres of activity of professional middle-class men." (Kelly, 1990: 110)

Closely related to the idealization and sublimation of the moral nature of women was the concept of the double standard. Throughout the seventeenth and eighteenth centuries conduct books taught young women that, while a wife had to be above reproach, she had to tolerate a much lower order of conduct from her husband. No matter what the husband's offences were, a dutiful wife continued to love and obey him with cheerfulness and submission. ${ }^{9}$ Elizabeth Hamilton even welcomed this double standard of morality and chastity which discriminated against women, because she firmly believed that it caused women to behave more virtuously than men. In fact, she goes so far as to say that those women who denounce that offences against morality are not equally judged, "may pique themselves on being the champions of their sex, but they are the enemies of society."10 (Hamilton, 1813: 322)

Obviously, since all the power inside marriage resided in the husband, very often marriage became a real nightmare for women. A married woman had no legal status. Therefore, if the husband turned out to be a tyrant and a brute, the woman could do nothing to defend herself, since the law sanctioned his absolute power and authority within marriage. In The Hardships of the English Laws in Relation to Wives (1735) the author states that the situation of married women is worst than that of slaves and provides a very illustrative example of the extent to which the legal system endorsed patriarchal power:

The next Instance I shall produce, is the Case of Mr. Veezey, tryed at the Old Bailey, where it was proved that he confined his Wife for some Years in a Garret, without Fire, proper Cloathing, or any of the Comforts of Life; that he had frequently Horse-whipt her; that her Sufferings were so great and intolerable, that she destroyed her wretched Life by flinging herself out at the Window.

But as there was Bread found in the Room, which, though hard and mouldy, was supposed sufficient to sustain Life; and as it was not thought that he pushed her out at the Window himself, 
he was acquitted, and that Complaint of her Sufferings served only to instruct Husbands in the full Extent of their despotick Power. (1991:219)

Since women's future happiness depended so much on attracting or choosing the right husband, many conduct books made special emphasis on it. Thus the Marquis of Halifax in The Lady's New-Year's Gift: or, Advice to a Daughter (1688) describes the kind of husband his daughter should wish for: "With all this, that which you are to pray for, is a Wise Husband, one that by knowing how to be a Master, for that very reason will not let you feel the weight of it; one whose Authority is so soften'd by his Kindness, that it giveth you ease without abridging your Liberty." (Savile, 1991:21) In An Unfortunate Mother's Advice to Her Absent Daughters Lady Sarah Pennington shudders at the thought of her daughters marrying a tyrannical husband: "May Heaven, in mercy, guard you from this fatal error!" (Pennington, 1966: 153)

Of course, this survey of the nature of marital relationships in the eighteenth century would not be totally accurate if I did not mention the change from arranged to companionate marriage that took place at least within the realm of ideas (Stone, 110). The notion that marriage was a concern primarily of the couple rather than the family gained credence during the period and by mid century friendship, mutual esteem and affection, rather than passionate love, were thought to be the proper basis of a happy marriage. If husbands and wives were to be companions they clearly had to have some liking for each other, some affinity or sympathy. John Gregory develops this concept in A Father's Legacy to his Daughters (1774):

In short, I am of opinion, that a married state, if entered into from proper motives of esteem and affection, will be the happiest for yourselves, make you most respectable in the eyes of the world, and the most useful members of society. But I confess I am not enough of a patriot to wish you to marry for the good of the public. I wish you to marry for no other reason but to make yourselves happier. When I am so particular in my advices about your conduct, I own my heart beats with the fond hope of making you worthy the attachment of men who will deserve you, and be sensible of your merits. (Gregory, 1991: 52)

Thus, there is a tendency towards a more egalitarian and humane model of marriage and a challenge to the patriarchal and authoritarian family type. Courtship became a time to know each other, to explore those qualities of mind and character which would help to form a relationship based on mutual esteem and common interests. As Brophy has shown, many of the letters written during the eighteenth century testify to the existence of many happy marriages in which companionship and love united. But although the notion of companionate marriage gained many adherents during the Enlightenment period, unfortunately, the legal basis remained the same ${ }^{11}$ and therefore women had nothing to glorify on, especially those married to tyrannical husbands:

The struggle between a generalized, egalitarian rationality and the concrete experiences of inequality under the law framed Mary Wollstonecraft's and Mary Hays's reflections on how little had changed for women at the end of a century of alleged enlightenment, rights talk, and contract logic. (Anderson, 2002: 56) 
Even Stone, one of the greatest defenders of the prevailing dominance of companionate marriage in the eighteenth century, admits that whether a relationship was successful or not still depended on the docility and adaptability of women, thus generating much frustration and disappointment amongst many women who had expected a more radical change in marital arrangements. As a matter of fact, Perry, who disagrees with Stone's assertion that women's role as their husbands' companion elevated them to the highest state in society, has emphasized how the new concept of marriage only led to a new colonization of women: "Educating women to be more interesting companions for men rather than as individuals with their own economic or intellectual purposes is an ambiguous advance, not one that moves very far along the path toward equality." (Perry, 1992: 192)

In "'I Died for Love': Esteem in Eighteenth-Century Novels by Women" Backscheider (1987: 160) asserts that novels about marriage have always tended to be darker than those about courtship and that the eighteenth century's are no exception. If we take into consideration what I have said about the situation of married women during that period, it becomes clear why whenever women writers decided to portray everyday life inside marriage, the overall picture became rather sad and disappointing. Novels such as Elizabeth Griffith's The History of Lady Barton (1771), Charlotte Lennox's Euphemia (1790) or Clara Reeve's The School for Widows (1791) describe with great realism the daily misery of an unhappy marriage. As Green has explained in The Courtship Novel we also find this grim description of marriage in the novels that end up with the happy union of the hero and the heroine and a future of conjugal bliss:

Indeed, if one is tempted to read courtship novels solely as propaganda that duped women into unwary acceptance of a domestic ideal, one should remember that although these novels generally concluded with the obligatory wedding and a foreshadowing of conjugal bliss, their minor characters alone - women won with promises, ruined, and abandoned, wives turned shrews would have sufficed as a warning about how uncommon the ideal domestic relationship was in real life. For every love match depicted in novels, periodicals, and conduct books, there were several exposés of failed marriage. (Green, 1991: 53)

Certainly, Adeline Mowbray must be included amongst the novels that offer us a realistic picture of the brutality and pain of domestic life. As a matter of fact, most critics consider that Adeline Mowbray is the result of Opie's ambivalent attitude towards patriarchy and its abuses, thus showing the conflict between what "it seems to mean officially and what it says unofficially" (Kelly, 1981: 17). They believe that although Opie seems to be supporting conventional values, what she really is doing is criticizing traditional institutions such as marriage that enslave and oppress women. Behind a façade of conformity to the established rules, Opie is subverting the Burkean ideal of the benevolent patriarch, showing how men tend to abuse their authority, becoming real tyrants instead of the figures of protection and security they are supposed to be. Eberle summarizes all these ideas when she explains that "Opie's negative characterization of Adelina's legal marriage is perhaps her most overt subversion of conventional morality." (Eberle, 1994: 140)

Obviously, it cannot be denied that Opie offers us in Adeline Mowbray a dark image of the powerlessness and vulnerability of married women. Sir Patrick is anything but the 
personification of the benevolent head of the household:

In his dealings with men, sir Patrick was a man of honour; in his dealings with women, completely the reverse: he considered them as a race of subordinate beings, formed for the service and amusement of men; and that if, like horses, they were well lodged, fed, and kept clean, they had no right to complain.

As a matter of fact, he behaves as a real gentleman in his duel with Glenmurray: he brings no second with him because he knows Glenmurray will find it difficult to get one himself, and when Glenmurray becomes injured he offers his chaise to take him back to Bath. But as a husband he proves to be the authoritarian figure who knows that law and social mores concede him all the power and property inside marriage. He marries Editha Mowbray to control her fortune and with the expectation of seducing her daughter, thus proving to be a tyrant and a libertine.

Berrendale is not the ideal husband either: he seems to have assimilated with great accuracy everything conduct books say about wives' submissiveness and devotion to their husbands. For him it is a truth universally acknowledged that women are born to please and content men. In fact, what first attracts him about Adeline is not her beauty or intelligence, but rather her ability to please Glenmurray:

...great then was his astonishment to find this imagined pedant, and pretender, not only an adept in every useful and feminine pursuit, but modest in her demeanour, and gentle in her manners: little did he expect to see her capable of serving the table of Glenmurray with dishes made by herself, not only tempting to the now craving appetite of the invalid but to the palate of an epicure, - while all his wants were anticipated by her anxious attention, and many of the sufferings of sickness alleviated by her inventive care. (142-3)

Their marriage goes very smoothly during the first six months because Adeline fulfils to perfection what are supposed to be a wife's duties:

For the first six months the union promised well. Adeline was so assiduous to anticipate her husband's wishes, and contrived so many dainties for his table, which she cooked with her own hands, that Berrendale, declaring himself completely happy for the first time in his life, had not a thought or a wish beyond his own fire-side. (180)

But this balmy situation does not last long. Berrendale, aware of the power and authority that law concedes him, decides to exercise them with great harshness. The first time he shows his real tyrannical side is when he discovers that Adeline has been spending too much on food. The poor Adeline has just been trying to content her husband by making life pleasanter for him, but he reproaches her for not having been able to manage the economy of the house successfully, as a perfect wife should do. Adeline promises to eat less in the future, since a little suffices her, to which Berrendale answers:

"Still, I think I have seen you eat with a most excellent appetite," said Berrendale, with a very significant expression. 
Adeline, shocked at the manner more than at the words, replied in a faltering voice, "As a proof of my being in health, no doubt you rejoiced in the sight."

"Certainly; but less robust health would suit our finances better." (181)

For the first time Adeline realizes that a woman's worst nightmare, that of being tied to a selfish and despotic man who treats her as a slave, has become true for her. She soon gets accustomed to his sarcastic and wounding speeches, as when Berrendale unexpectedly arrives home and finding Adeline playing with Editha in the parlour, recriminates her for having everything out of order. Adeline humbly says that if she had known that he was going to come back so soon she would have had everything ready for him, to which Berrendale does not hesitate to reply:

"There - there you go, again.- If I say but a word to you, then I am called unkind, though, God knows, I never speak without just provocation: and, I declare, I came home in the best humour possible, to tell you what may turn out of great benefit to us both: - but when a man has an uncomfortable home to come to, it is enough to put him out of humour." (192)

Again, Berrendale shows to know by heart the rules of conduct books, especially the one that says that marital harmony is the responsibility of the wife and that therefore her attitude should always be one of loving and cheerful submissiveness. ${ }^{12}$

Since Berrendale is not doing anything that has not been sanctioned by law, religion or social rules, he really becomes surprised when Adeline tells him that her black servant Savanna is the only person who really loves her:

He was conscious, indeed, that his fidelity to his wife had not been proof against a few weeks' absence; but then, being, like most men, not over delicate in his ideas on such subjects, as soon as Adeline returned he had given up the connection which he had formed, and therefore he thought she had no much reason to complain. In all other respects he was sure that he was an exemplary husband, and she had no just grounds for doubting his affection. He was sure that she had no reason to accuse him of unkindness; and, unless she wished him to be always tied to her apronstring, he was certain he had never omitted to pay her all proper attention. (188)

Berrendale, clinging to the double standard of the age, is not very worried about the affair he has had with one of the maids while Adeline has been away, ${ }^{13}$ but with great cruelty reminds his wife that he showed his affection for her when he decided to marry a woman like her who had been the mistress of another man. Berrendale is just ratifying what I explained before, that whereas the wife was "expected to be a virgin on her wedding night... the man was expected to have gained some sexual experience before marriage, and any infidelities after marriage were treated as venial sins which the sensible wife was advised to overlook." (Stone, 1990: 315)

Berrendale's attitude towards Adeline illustrates not only the powerlessness of married women but also how uncommon was the ideal domestic relationship in real life, since whether a marriage was companionate or not depended entirely on the husband and he was not always willing to give up the 'sacred' authority that had been invested on him. Opie was aware of that 
bleak reality and therefore uses Adeline Mowbray to destroy any idealization both of traditional and companionate marriage and tell her female readers not to expect much from life or to dream of a more egalitarian relationship between husband and wife, because this was not very often the case. By doing so Amelia Opie is going against a whole tradition of female writing that in the last decades of the eighteenth century had encouraged the tendency towards companionate marriage, defending women's right to chose their partners for personal rather than familial or economic reasons. Women writers were looking for another alternative for their heroines that did not include being tied to despotic husbands and they found it in the creation of a new model of marriage based on cooperation and equality. ${ }^{14}$ Of course, this demanded the creation of a new kind of hero, what has sometimes been called the "new feminized man", who proves to be an exception to the patriarchal figure. The new hero is converted to more egalitarian and feminist principles and is willing to curtail the rights with which patriarchy has invested them in order to give the heroine some scope for the exercise of her judgment: “....a significant number of women writers - whether conservative or radical - were seeking to transform the powerful father figure from a frightening oppressor into an ideal suitor and future husband who would use his power to authorize a woman's being rather than destroy it. In other words, these writers imagined men as disciplining their desires." (Wikborg, (2002: 11) The ideal lover is open to the needs of others and shows the unassertiveness, modesty, meekness, passivity, tenderheartedness and compassion usually associated with women. He is also aware of the moral and intellectual superiority of the heroine. Thus the stereotype of the aggressive and dominant male which prevailed in the conduct books and many novels of the age is avoided. It is obvious that these writers knew that the hero they had created was just an ideal difficult to find in real life and that the road to companionate marriage was a hard one. ${ }^{15}$ Theirs was merely a "fantasy of power" (Newton, 1981; Rogers, 1982; Hoeveler, 1998), but it was the only option they had if they wanted to reward their heroines in a world that did not offer women many chances of self-fulfilment: "In many ways, the brother-protector is presented as 'ideal' and rather two dimensional compared to the more 'real', seductive and dangerous male characters, and to some extent, they can be read as the ultimate fiction of the narrative." (Forbes, 1995: 302)

Opie refuses even this alternative, because, although it may contribute to paving the way for a more egalitarian type of marriage, reality is far more painful and oppressive for women. It is true that Glenmurray seems to represent the new hero women writers were promoting: he has got the delicacy and moral tact that Berrendale lacks, is aware of Adeline's moral and intellectual superiority and wants a relationship based on egalitarian principles. As a matter of fact, most critics have underlined this aspect of the novel. In Empowering the Feminine Ty affirms that the only two positive heterosexual relationships in the novel are those of Adeline and Glenmurray and $\mathrm{Mr}$ and Mrs Pemberton, and Kelly, who defines Glenmurray as a philosophic Byronic hero, argues that an "unofficial reading" of Adeline Mowbray allows us to see a model relationship in the union of Adeline and Glenmurray. Eberle, who is not so benevolent with Glenmurray, since he sees him as Adeline's seducer and criticizes his readiness to sacrifice her in the name of his theory, knowing what the world's reaction will be, nevertheless points out the way in which Amelia Opie encourages a positive reading of the relationship between Adeline and Glenmurray. King and Pierce also believe that the union 
of the two main characters is an example of "an intellectually, emotionally, and sexually fulfilling (but unmarried) relationship", (King and Pierce, 1999: xvii), whereas Howard sees Opie's affection for the proponents of liberal philosophy in the sympathy with which Adeline and Glenmurray are treated and in the way in which "their illicit but happy love affair easily outshines the bleak representations of married life" (Howard, 1998: 357).

It must be admitted that the first image we get of Glenmurray is that of a sensitive, sensible and virtuous man. We are told of "the blamelessness of his life,... his active virtue, assisted by the most courteous manners" (21) and explained that his great error was to give his eccentric ideas too soon to the world, thus prejudicing society against him. His sensibility and virtuous character become obvious from the very beginning of the novel. Thus when he realizes that people are laughing at Mrs Mowbray and Adeline because they are talking to him, "heroically sacrificing his own gratification to save Mrs Mowbray and Adeline form further censure" (24) he leaves them. He also shows his generosity when he declines Mrs Mowbray's invitation to a party at her house, although he would be delighted to go, since he knows that he will be exposing her to very disagreeable remarks. But this young man who seems to be free from all kinds of sanctioned customs and defies the ideological construct of man, very soon proves to be prey to social rules and thus fails in his role as the new kind of companionate partner. When Sir Patrick challenges him to fight a duel, he is so overburden by social prejudices, that he cannot decline it. He, who "has written a volume to prove the absurdity of the custom" (30) is afraid of others thinking him weak and cowardly if he refuses to fight. As he explains to the perplexed Adeline after the duel: "'But I should have been called a coward had I declined the challenge; and though I can bear the world's hatred, I could not its contempt: - I could not endure the loss of what the world calls honour." (36). ${ }^{16}$ Glenmurray is subscribing here to the view most common in conduct books that men must be defined by their strength and courage and that, therefore, anything that proves them to be faulty in any of these two qualities could destroy their honour and reputation. In other words, Glenmurray, an apparently sensitive, kind man is trapped in those prejudices that have helped to build the ideological image of both man and woman. This concern for his honour, or what society considers to be a man's honour, becomes clear when he reflects for the first time on the possibility of marrying Adeline: "Well; - so much for principle and consistency! Now, my next step must be to marry, and then I shall have made myself a complete fool, and the worst of all fools, - a man presuming to instruct others by his precepts, when he finds them incapable even of influencing his own actions." (35). Glenmurray's thoughts are very revealing because, as Stone has explained, the concept of honour in the eighteenth century had a different meaning for men and women: "Thus a man's honour depended on the reliability of his spoken word; a woman's honour on her reputation for chastity." (Stone, 1990: 316) Glenmurray is not so much worried about Adeline and the disastrous consequences of her living with him without being married, but about the world's opinion of him, an opinion he alleges all the time to despise. Glenmurray knows how much Adeline is going to suffer if they decide to live together and tries to convince himself that if it were not for the fear of provoking Adeline's indignation - she is convinced of the validity of his ideas - and being further ridiculed by the world on account of his contradicting his own theory, he would ask Adeline to marry him. This somehow contradictory attitude of Glenmurray - on the one hand, worried about Adeline and, 
on the other, being too much concerned about the world's opinion - which disqualifies him as the appropriate partner for an egalitarian relationship, is given the final touch when the narrator provides us with the following explanation for Glenmurray having entertained the idea of marrying Adeline:

Glemmurray thought that he was willing to marry Adeline merely for her sake; but I suspect it was chiefly for his. The true and delicate lover is always a monopolizer, always desirous of calling the woman of his affections his own: it is not only because he considers marriage as a holy institution that the lover leads his mistress to the altar; but because it gives him a right to appropriate the fair treasure to himself, - because it sanctions and perpetuates the dearest of all monopolies, ${ }^{17}$ and erects a sacred barrier to guard his rights, - around which, all that is respectable in society, all that is most powerful and effectual in its organization, is proud and eager to rally. (38)

Glenmurray, who has the same liberal ideas on marriage as Godwin, ${ }^{18}$ when faced with reality cannot forget the power and authority that social mores, religion and law concede him and would like to marry Adeline in order to own her as his property. Obviously, this paragraph could be read as an instance of Glenmurray's devotion and passion for Adeline, as King and Pierce have hinted, but I believe that the message is much deeper: unless the legal system changes, it will be very difficult for women to enter a more egalitarian relationship. Glenmurray also, as Eberle has pointed out, "rejects the rites of society which name women 'wives', but he continues to use society's vocabulary to name them 'whores"' (Eberle, 1994: 138), by employing the term "mistress" to refer to Adeline.

Nevertheless, we become for a brief moment "reconciled" with Glenmurray when his affirms that "I love my system and my opinions, but the respectability of the woman of my affections more." (46). But, although he has decided to make Adeline legally his wife, he keeps postponing the ceremony, thus transforming Adeline's life into a path of thorns. She cannot go with "proper ladies" because they would despise her, as she learns when Glenmurray tells her that Mr Maynard would not think her a fit companion for his sisters. Glenmurray seems to be deeply affected by the brutal way in which society treats such a virtuous and honest creature as Adeline: men believe that because she lives with a man without the marriage vows she is a "woman of vicious inclinations" (116) and therefore eager to engage with other suitors, while women reject her for having transgressed the rules of propriety. His health gradually deteriorates, but the interesting point is that he does not do anything to put an end to Adeline's suffering, of which he is the main cause. Major Douglas confronts Glenmurray on the subject: "But what vexes me is...that you should have turned the head of that sweet girl. The opinion of the world is every thing to a woman." (82). Glenmurray acknowledges that he would like to marry Adeline to save her from abuse, but she is so convinced of the validity of the ideas he has exposed in his books, that she does not want him to compromise his theories. ${ }^{19}$ Douglas answers that if Adeline forgot that it was Glenmurray who wrote those books "then they would appear to her, as they must do no doubt to all people of common sense, and that is, abominable stuff' (82). Douglas's statements are very revealing because they show how Glenmurray's attitude to Adeline's misery is rather a passive one: he does not act as the benevolent head of the family who tries to protect and save its members from danger. It is true that Glenmurray is always asking Adeline to marry him, but all the time 
the reader has the feeling that he is not insistent, that he who dominates the world of ideas so well could find a way to convince his lover. He is even afraid of confronting face to face those who disagree with his theories. Thus, when Adeline pleads with him to talk to Mr Maynard to explain the real basis of their relationship, he just gives excuses and instead writes a letter to him.

Dr Norberry is admired by the amiable disinterestedness of Adeline and Glenmurray who are ready to sacrifice what is dearest to them - she her reputation, he his own ideas - in order to make the other happy. He even hints at the egalitarian nature of their relationship: "And now here you are, possessed of every quality both of head and heart" (90). But it is obvious that Adeline's "offering" has more negative consequences for her than for Glenmurray: Adeline's crime will never be forgotten or forgiven by a society which such strict rules on female modesty and chastity, whereas Glenmurray will always have the opportunity of starting a new life ${ }^{20}$. In other words, the one who gets victimized in a patriarchal system is always the powerless, the helpless, that is to say, the woman. Glenmurray himself admits that he is ashamed of what he has done to Adeline, but it is too late. He only has the courage to tell Adeline that he has realized that society is not yet prepared for such advanced theories on marriage as his when he is on his deathbed and not before, when he could have done something to save her from so much pain. On top of that, it is Adeline who must always play the submissive role and adapt herself to Glenmurray's wishes. This becomes very clear when his cousins announce their visit and Glenmurray says to Adeline that she cannot see them: "'I understand you,' replied Adeline, changing colour: 'they will not deem me worthy,' forcing a smile, 'to be introduced to them." (126). Glenmurray replies that he will forbid their coming, but Adeline insists on Glenmurray seeing them. Nevertheless, she cannot help reflecting with great pain on her lover's failure to defend her and on how trapped he is in the net of social prejudices:

Nor was she entirely satisfied with Glenmurray's conduct: - true, he had earnestly and sincerely wished to refuse to see his unexpected and unwelcome guests; but he had never once expressed a desire of combating their prejudices for Adeline's sake, and an intention of requesting that she might be introduced to them; but, as any common man would have done under similar circumstances, he was contented to do homage to "things as they are", without an effort to resist the prejudice to which he was superior." (126)

Astonishingly enough, when the cousins leave, it is Adeline, the humiliated and trodden one, who has to console Glenmurray, who is overwhelmed by guilt and mortification: "Adeline...affected the cheerfulness which she did not feel" (127). The situation seems to be taken out of a conduct book: no matter what the husband's offences may be, the wife should remain cheerfully loving. The real fact is that by the end of a relationship that most critics have described as a "model", but which seems to have entailed only pain and misery, the heroine has been completely destroyed by the hero, as he himself acknowledges: "'I must open my whole heart to you, and confess that the idea of leaving you friendless, unprotected, and poor, your reputation injured, and your peace of mind destroyed, is more than I am able to bear, and will give me, in my last moments, the torments of the damned."' (149). He knows that society will not forgive her for her sins and that therefore it will be very difficult, not to say 
impossible, for her to find a job, in spite of the fact that she is well qualified to be a teacher. He realizes that the only option left for her is marriage, but is aware of the fact that with her past not many men are going to be willing to marry her. Therefore he pleads with her to marry Berrendale. Eberle has interpreted this passage as Glenmurray "selling" Adeline as a good nurse and housekeeper and adds: "On his deathbed, he encourages Adeline to marry his cousin, asking her to give up both her philosophical and moral principles by embarking on a legal union with a man she does not love." (Eberle, 1994: 138) I disagree with Eberle. I think that Glenmurray is just being realistic about Adeline's future: he knows that there is no social forgiveness for those who transgress the established boundaries and that, therefore, if she does not marry Berrendale she will be reduced to a life of poverty and destitution or, even worse, fall in the clutches of prostitution. ${ }^{21}$

In Empowering the Feminine, Ty points out that, unlike Godwin's Memoirs, Adeline Mowbray does not finish with the reward of romantic and domestic retreat or with the discovery of the true patriarchal protector. According to Ty, this allows us to interpret the novel as "a study of the slow and painful defeat and debilitation of a strong, rebellious, and generous spirit" (Ty, 1998: 156). I will not disagree with Ty, but will add that there is no benevolent patriarchal figure, because he does not exist, not even Glenmurray, as we have seen, fulfils this role. The harm that Glenmurray inflicts on Adeline is the same that patriarchal heads without scruples produce on helpless creatures. For society there is no difference between Adeline and those women who have been seduced and become fallen women. Opie explains it very well in the novel:

If Glenmurray, who had been the means of injuring the woman he loved, merely by following the dictates of his conscience, and a love of what he imagined to be truth, without any view to his own benefit or the gratification of his personal wishes, felt thus acutely the anguish of self-upbraiding, what ought to be, and what must be, sooner or later, the agony and remorse of that man, who, merely for the gratification of his own illicit desires, has seduced the woman who he loved from the path of virtue, and ruined for ever her reputation and her peace of mind! (157)

Critics have explained again and again how Opie uses the novel to show the gap between Godwin's theory and its shortcomings when applied to women. But King and Pierce have added an element that I find very revealing. They argue that Opie is not so much rejecting Godwin's philosophy as Godwinian optimism regarding human nature and I think this is the main point in Adeline Mowbray. Opie knew that there would not be any changes in the relationships between men and women unless the legal system was altered and men were deprived of their power and authority. Meanwhile, whether a marriage, or a union such as that of Glenmurray and Adeline, was happy or not depended entirely on the attitude of the husband. Many women writers created this new hero who is converted to more egalitarian principles, but Opie thought that it would be dangerous to offer her readers a fantasy which in real life rarely became true. Adeline expresses this grim truth when referring to Glenmurray's, that is to say, Godwin's belief that relationships should last as long as both parties want them to, affirms: 
It has been said, that, were we free to dissolve at will a connection formed by love, we should not wish to do it, as constancy is natural to us, and there is in all of us a tendency to form an exclusive attachment. But though I believe, from my own experience, that the few are capable of unforced constancy, and could love for life one dear and honoured object, still I believe that the many are given to the love of change; - that, in men especially, a new object can excite new passion and, judging from the increasing depravity of both sexes, in spite of existing laws, and in defiance of shame, - I am convinced, that if the ties of marriage were dissolved, or it were no longer to be judged infamous to act in contempt of them, unbridled licentiousness would soon be in general practice. (237-8)

If companionate marriage is an unattainable ideal and patriarchal marriage a nightmare, what option is left for women? Some critics have suggested that Opie proposes the creation of a community of women who will help and support each other morally and economically. Thus Ty points out how the only two people who really help Adeline and remain her faithful friends and companions are two substitute mother-figures, Savanna and Rachel Pemberton. Unlike Berrendale and Editha Mowbray who abandon Adeline when she most needs them, Savanna and Mrs Pemberton remain devoted to the heroine. Howard has also argued that the novel establishes a community of mothers and daughters, a maternal order, as the solution to the problems of the text, but, in contrast to Ty, also includes in this group the reformed Editha. Eberle agrees with Howard that the novel concludes with a vision of interdependent female unity, of women committed to one another and with enough economic power to be free from any patriarchal pressures. This strong female community that will offer its compassion and protection also to the fallen women, is composed of Mrs Pemberton, Mrs Mowbray and Savanna. ${ }^{22}$ King and Pierce are also of the opinion that by creating a community of "amiable" women, women of thought and feeling who understand and sympathize with Adeline's plight, Opie is offering some hope to the female reader. Where they differ from other critics is not only in including Emma Douglas in this society instead of Editha Mowbray, but also in suggesting that this emphasis on what Anne Mellor has called "feminotopia", should not let us forget the importance of one of the male characters, Dr Norberry, who shares many qualities with the amiable women: "The figures who surround Adeline are those who can combine compassion with an ability to explore ideology. Adeline Mowbray asks of its readers a similar flexibility of mind and ability to discriminate complex moral issues." (King and Pierce, 1999: xxxii)

I have reproduced this last quotation because what I want to demonstrate is that two of these women who are supposed to be generous and amiable are really defined by their lack of compassion and "flexibility". I am referring to Rachel Pemberton and Emma Douglas. Both of them are shaped by social prejudices and confirm the age's ideology on female chastity and decorum. ${ }^{23}$ James Fordyce, whose Sermons to Young Women, as I said above, was reprinted after the revolutionary period, asserted that chastity was a woman's treasure and Wetenhall Wilkes in A Letter of Genteel and Moral Advice to a Young Lady (1740) makes a real apologia for this female virtue:

Chastity is the next virtue, that is to fall under your consideration; no charm can supply its place; without it beauty is unlovely, wit is mean and wanton; quality contemptible, and good-breeding 
worthless. She, who forfeits her chastity, withers by degrees into scorn and contrition; but she, who lives up to its rules, ever flourishes, like a rose in June, with all her virgin graces about her - sweet to the sense, and lovely to the eye. (Wilkes, 1991:29)

He warns of the dangers of defiling chastity and does not hesitate to say that "an immodest woman is a kind of monster, distorted from its proper form" (Wilkes, 1991: 30). Years later in the counterrevolutionary period conservative writers such as Hannah More are going to reinforce the validity of these statements. In Strictures on the Modern System of Female Education (1799) More affirms that propriety "is to a woman what the great Roman critic says action is to an orator; it is the first, the second, the third requisite" (More, 1991: 131-2). and denounces the dangerous messages of many novels, pointing at Rousseau as the first popular dispenser of this complicated drug: "He does not paint an innocent woman, ruined, repenting, and restored; but with a far more mischievous refinement, he annihilates the value of chastity, and with pernicious subtlety attempts to make his heroine appear almost more amiable without it...he gives to vice so natural an air of virtue..."24 (More, 2003: 326-7). She attacks those writers, including the female Werter, that is to say, Wollstonecraft, who justify adultery and paint the heroine who has violated the seventh commandment so amiable and benevolent that the reader forgets the horror of the crime she has committed. But in spite of the pernicious influence of these books, More thinks that there is no reason to despair, since thanks to the efficacy of holy religion and "virtuous" laws, "this crime, in the female sex at least, is still held in just abhorrence" (More, 1991: 135-6). What is most revealing about More's text is her attitude towards fallen women:

And, while you resolutely persevere in making a stand against the encroachments of this crime, suffer not your firmness to be shaken by that affectation of charity, which is growing into a general substitute for principle. Abuse not so noble a quality as Christian candour, by misemploying it in instances to which it does not apply. Pity the wretched woman you dare not countenance; and bless HIM who has 'made you to differ'. If unhappily she be your relation or friend, anxiously watch for the period when she shall be deserted by her betrayer; and see if, by your Christian offices, she can be snatched from a perpetuity of vice. But if, through the Divine blessing on your patient endeavours, she should ever be awakened to remorse, be not anxious to restore the forlorn penitent to that society against whose laws she has so grievously offended; and remember, that her soliciting such a restoration, furnishes but too plain a proof that she is not the penitent your partiality would believe; since penitence is more anxious to make its peace with Heaven than with the world. (More, 1991: 136)

More's idea that a fallen woman could not be rehabilitated was shared by many conservative writers, but some of them argued that pity should be shown towards those who had repented of their sins. Thus, although Hamilton used the expression "excess of charity" to warn her female readers of the danger of false sentimentality contributing to "lessening the love of virtue and the abhorrence of vice." (Hamilton, 1813:311), so "that the period is not far distant when the adulteress and chaste matron will be universally received upon equal terms." (Hamilton, 1813: 314), she nevertheless believed that that a fallen woman should be pitied and comforted: "As vice is the object of moral disapprobation and abhorrence, and, according to the authority of the religion we profess, exposes the impenitent sinner to the 
penalty of everlasting perdition, the vicious are certainly the proper objects of our compassion; nor can a truly benevolent mind consider their unhappy state, without feelings of pity and commiseration." (Hamilton, 1813:308)

Interestingly enough, radical writers such as Hays, Macaulay and Wollstonecraft also celebrated chastity, but they did so in order to destroy the double standard which expected women to be more virtuous than men. They also reflect a more compassionate attitude towards fallen women. In Appeal to the Men of Great Britain in behalf of the Women (1798) Hays attacks the licentiousness of men, who should be "more guarded and exemplary" in their character and conduct and encourages women to possess the "amiable" and "indispensable" virtue of modesty. She asks virtuous women to show humanity and compassion towards the fallen ones:

And indeed I cannot help considering it as a matter of great importance to society, to inculcate; that compassion and an attention to the circumstances which may have led to the destruction of such, are more likely means of producing reformation among them, and stopping the progress of vice; than that hatred, contempt, and terror, which the modest and virtuous, perhaps, naturally enough feel for such characters, when these are not taken into consideration. (Hays, 1991: 237)

Hays points out that men are always responsible for women's fall, having no scruples in defiling the very same virtue they themselves describe as the chief bond of society. Also, unlike most conservative thinkers, Hays believes that some women are capable of returning to the path of rectitude, thus proving "that in some minds nothing can totally extinguish the love of virtue" (Hays, 1991: 237).

Catherine Macaulay agrees with Hays that a first fault must not necessarily lead to a woman's destruction and adds that if this often happens it is because "they are thrown into a state of desperation, by the venomous rancour of their own sex." (In Wollstonecraft, 1993: 226) She also calls for equality in virtuous behaviour and sympathy for fallen women:

A woman...who, understanding the principles of true religion and morality, will regard chastity and truth as indispensible qualities in virtuous characters of either sex; whose justice will incline her to extend her benevolence to the frailties of the fair as circumstances invite, and to manifest her resentment against the underminers of female happiness; (Macualay, 1991: 116)

Wollstonecraft also claims for equality of knowledge and virtue: "Chastity, modesty, public spirit, and all the noble train of virtues, on which social virtue and happiness are built, should be understood and cultivated by all mankind, or they will be cultivated to little effect." (Wollstonecraft, 1993: 229)

We would expect Rachel Pemberton and Emma Douglas to show that compassion for Adeline that radical writers are proclaiming. As a matter of fact, some critics have argued that Adeline Mowbray questions the way in which virtuous and non-virtuous women are categorized by society, thus challenging the clear-cut division between what is morally worthy and morally contemptible. We would expect "open-minded" and "benevolent" women such as Mrs Pemberton and Emma to be able to acknowledge Adeline's virtues and thus be at her side from the very first moment. But Mrs Pemberton only gives Adeline real support when she 
is on her deathbed and Emma not even that. ${ }^{25}$ Although they seem to be aware of Adeline's worth, they have internalised social prejudices to such an extent that they can only see her in terms of her sexual and social violations. Unlike Savanna, who sometimes subverts the social rules, but whose unconditional love and devotion for Adeline is unquestionable, ${ }^{26}$ and Editha, who has to learn from her errors, Emma and Mrs Pemberton appear from the very beginning as angels of perfection and as such, interestingly enough, they have been described by critics. We have seen how Ty points out Rachel Pemberton's faithfulness to Adeline, whereas for Howard she is the most sage and charitable woman in the novel, an idealized, although absent, mother figure for Adeline, who possesses the qualities of sense and moderation that are associated with moral motherhood. Eberle thinks that although the Quaker lady regrets Adeline's action, she acknowledges her intrinsic virtue. A similar idea is put forward by King and Pierce, who offer us a more idealized picture of Rachel Pemberton. According to them, she is a figure of rational sympathy and instruction who, influenced by Quaker ideas, "shares many of Adeline's ideals, and an understanding, despite her disagreement, of her need to follow the dictates of conscience rather than the regulations of society" (King and Pierce, 1999: xxix). She shows sympathy for Adeline's plight and instead of condemning her for her sexual transgression, argues rationally with her and offers her her help in case she should need it. She also makes Editha Mowbray aware of her mistakes as a mother and achieves a reconciliation between her and Adeline.

It is clear that Mrs Pemberton at certain moments shows compassion for Adeline, like when she accepts to employ Mary against her own principle of not having in her house servants whose previous mistress has defied the rules of society. It is also true that Mrs Pemberton, who is defined by her self-command, cannot control herself at the sight of Adeline's suffering and pours out her feelings. This happens, for example, when she visits Adeline after Glenmurray's death or on contemplating the heroine's agony in her last days. Even Dr Norberry who is prejudiced against the Quakers because of their pretensions to righteousness and formality, surrenders to her. But she, who seems to appreciate Adeline so much, is never there to help her when she really needs her. We are told that she has a friend to look after, but the fact is that Adeline has to endure alone the pain caused by society's rejection, Glenmurray's death and the marriage to Berrendale. It is also very revealing that Adeline, although acknowledging Mrs Pemberton's benevolence, knows that she lacks her esteem because of her sexual transgression. That is why Adeline is so eager to write a letter to Mrs Pemberton telling her that she is now a married woman. Mrs Pemberton is only by the heroine's side when she "follows" Hannah More's advice and decides to atone for her past crimes by abandoning society and retiring to the country. As a matter of fact, throughout the novel Mrs Pemberton's benevolence is betrayed by her own language, which clearly expresses her total rejection and condemnation of Adeline's behaviour. These are, for example, two of the "friendly" speeches of Mrs Pemberton during her first interview with Adeline:

"... Surely, surely, thine heart accuses thee; for thy face bespeaks uneasiness, and thou wilt listen to the whispers of penitence, and leave, ere long, the man who has betrayed thee." (122)

"From the poor victim of passion and persuasion, penitence and amendment might be rationally expected; and she, from the path of frailty, might turn again to that of virtue: but for one like thee, 
glorying in thine iniquity, and erring, not from the too tender heart, but the vain-glorious head, for thee there is, I fear, no blessed return to the right way; and I, who would have tarried with thee even in the house of $\sin$, to have reclaimed thee, penitent, now hasten from thee, and for ever-firm as thou art in guilt." (122-3)

These fragments seem to be taken from one of the most conservative conduct books, which, as we saw above, considered a sexually transgressive woman a kind of monster who had to pay for her crimes. Mrs Pemberton illustrates this idea very well on saying to Adeline: "At Rosevalley I beheld thee innocent, at Richmond guilty, and here I see thee penitent, and, I hope, resigned to thy fate." (266). This same notion of $\sin$ is present again when Mrs Pemberton asserts that it is her duty to find Adeline "and reflect on my happiness if I am allowed to restore the lost sheep to the fold again" (256). Her idiolect includes expressions such as "children of error" (160), "thy mourning victim, may learn to bless the hand that chastises her" (160), "expiate your past follies" (252), "truly contrite spirit" (255), which are neither reassuring nor compassionate. Even when she meets Mrs Mowbray she wants to be sure that she is dealing with the right kind of person by inquiring about her in the neighbourhood on "whether her virtues at all kept pace with her misfortunes" (249). If the community of women proposed by Opie is mainly represented by Rachel Pemberton, then it is clear that the writer is not presenting an alternative to the patriarchal order that oppresses women, as most critics have argued, but pointing at the absence of any other options for women outside traditional marriage. Mrs Pemberton and the reformed Editha Mowbray reproduce the attitudes, manners and ideas sanctioned by patriarchal society and therefore do nothing but reinforce a repressive system. In this sense, it is very revealing that the daughter who has subverted the rules, Adeline, dies, and the daughter who has assimilated social customs and norms, Editha, is allowed to join the privileged group. The only woman who shows some signs of rebellion, Savanna, is immediately put under Mrs Pemberton's guidance.

The other amiable woman, Emma Douglas, is described in highly favourable terms by King and Pierce:

A woman of more character than beauty, she escapes society's schooling in coquetry and thus is able to focus her mind on issues other than her own marketability within the sexual economy. This in turn allows her to engage with Adeline's ideology more thoroughly than do other characters. Perhaps most important, her flexible intellect allows her to redefine "the world" in order to meet and exchange ideas with Adeline. (King and Pierce, 1999: xxx)

From this eulogy of Emma we would expect to discover a character who, as the narrator says, is one of the best of women. It is true that she is intelligent - "her remarks on whatever subject she conversed were formed always to interest, and instruct" (228) - and rejects the role of the coquette - "always humble in her ideas of her own charms" (235). It cannot be denied either that she is always ready to defend Adeline from those who slander and scorn her. Thus when her brother feels his pride wounded because his wife and sister have been talking not to Glenmurray's wife, but to his mistress, she asserts that Adeline is a virtuous woman who "seems to be more ill-judging than vicious"(79). And when Mr Maynard's sisters ridicule her, she not only repeats again the same idea that Adeline has been "the victim of a romantic, 
absurd, and false conception of virtue" (230), but regrets not having spent much more time with her. She is even flattered when Colonel Mordaunt says that there is something in her countenance that reminds him of Adeline. But although Emma, like Mrs Pemberton, seems to admire and love Adeline because she recognizes the virtuous woman in her, social prejudices do not allow her to lend the heroine the support she needs. Emma is always defending Adeline from the abuses of others, but we never really see her by Adeline's side offering her hand. The narrator hints at that reality during the first encounter between Adeline and Emma:

besides, she flattered herself, that, could she once interest these charming women in her favour, they would not refuse her their society even when they knew her real situation; for she thought them too amiable to be prejudiced, as she called it, and was not yet aware how much the perfection of the female character depends on respect even to what may be called the prejudices of others. (78)

As a matter of fact, Emma's main argument to persuade Adeline to marry Glenmurray is that, although she and her sister-in-law admire her, they will not associate with her unless she becomes Glenmurray's wife. She adds that they will go to the church with her and that she is sure that Adeline "will repeat her vows with more heartfelt reverence, when two respectable women, deeply impressed themselves with their importance, shall be there to witness them" (83). Obviously, Emma is endorsing the conventional dichotomy between the pure and the fallen woman and making it clear to which pole she belongs. Thus, although she seems to respect Adeline's virtuous and honest character, in practice she does not want her own reputation to be sullied by mixing with a "bad" woman. Emma's lack of flexibility and understanding of Adeline's real worth and her surrender to social usage becomes clear when she envisages the heroine's situation after Glenmurray's death: "whom I, on the contrary, believe to be at this moment atoning for the error of her judgment by a life of lonely penitence, or sunk perhaps already in the grave, the victim of a broken heart." (231). Hannah More would have been very proud of Emma Douglas!

And precisely in the marriage of this woman, who has totally assimilated the conventions of patriarchal society, and the reformed libertine Colonel Mordaunt do Eberle and King and Pierce see an example of the ideal of companionate marriage and thus a potential for social renovation. King and Pierce admit that Mordaunt is never really capable of understanding Adeline's worth, but argue that Emma with her recognition of Adeline's virtues and her pragmatic sense will complement her husband. I certainly disagree with this notion of Emma Douglas and Colonel Mordaunt representing a model relationship. A man who believes that in conduct Emma is superior to Adeline and who admits that he prefers to marry Emma "who had never erred, to Adeline who had" (235), is not really an example of a new hero converted to more egalitarian and humane principles, but a staunch defender of the status quo and therefore of patriarchal order. And a woman like Emma who represents perfection mainly because she respects the laws of modesty and decorum sanctioned by society, cannot represent the new kind of women Wollstonecraft was defending. Emma Douglas and Colonel Mordaunt's marriage will be a patriarchal one and whether they will be happy or not will depend entirely on Emma playing the role of the submissive and devoted wife, which is what 
Mordaunt expects of her, and of Mordaunt renouncing to be the tyrannical head of the household and the libertine he has been.

During the end of her life Amelia Opie reflected that 1794 had been the most interesting period of her life (Brightwell, 1854: 52) and Adeline Mowbray shows precisely the disappointment of a woman who knew that the revolutionary ideals of the 1790s, especially those that concerned women, would never be applicable in a country like England unless there was a radical change in law and social rules. She does not open up new possibilities for women, but makes them aware of the unchangeable nature of their predicament in an reactionary age in which the conservative ideological construction of woman is being reasserted. There is no room for enthusiasm or idealism in Adeline Mowbray because real life does not admit them. Eighteenth-century women writers were convinced of the fact that the novel was the best vehicle to educate women and offer them a true picture of their lives and "wrongs". Adeline Mowbray is merely the result of a novelist's desire to fulfil this important task.

\section{Notes}

1. Although most twentieth-century critics consider Opie a subversive writer, there are some exceptions. See Ina Ferris (1991).

2. Women writers were identified with their texts, so that if their behaviour was censurable, so was their work. A critic of 1807 explains this fusion of linguistic and physical purity with great accuracy: "The penalties and discouragements attending the profession of an author fall upon women with a double weight; to the curiosity of the idle and the envy of the malicious, their sex affords a peculiar incitement: arraigned, not merely as writers, but as women, their characters, their conduct, even their personal endowments, become the subjects of severe inquisition.” (In Zimmerman, 1991: 61)

3. As Ty has explained, even revolutionary sympathizers became more cautious. Thus friends and followers of Wollstonecraft like Mary Hays and Mary Robinson wrote essays about the condition of women in the last years of the eighteenth century, but because they were afraid of being rejected, published them either anonymously or under a pseudonym. The case of Hays is particularly revealing: not only did her production became more didactic and conservative with the turn of the century, but she, who had been a good friend of Wollstonecraft and had written two obituaries on her death, did not dare to include her in Female Biography; or, Memoirs of Illustrious and Celebrated Women, of All Ages and Countries (1803) for fear of being rejected by a more reactionary society. See Eleanor Ty (1994; 1998).

4. For the role of conduct books in contributing to creating the new domestic woman and the rise of the middle class in England see Nancy Armstrong (1989).

5. Many of the passive qualities attached to the new ideologically constructed woman - modesty, meekness, compassion, affability, humility - were already present in conduct books published at the end of the seventeenth century, beginning of the eighteenth century, such as The Ladies Calling (1673), by Richard Allestree, The Lady's New-Year's Gift: or Advice to a Daughter (1688), by the Marquis of Halifax, or The Whole Duty of a Woman: Or a Guide to the Female Sex from the Age of Sixteen to Sixty (1701).

6. Conservative writers were greatly influenced by Edmund Burke and the ideas he developed in Reflections on the Revolution in France (1790) and its sequel, Letter to a Member of the National Assembly (1791), in reaction to the revolutionary notions that were being introduced in England. Burke 
insists on the sacredness of paternal authority and patriarchal family relations and sees the family as a basic political unit in its own right. For Burke, love of the family will lead to love of society, one's own country and mankind.

7. Wollstonecraft comments with great irony: "Such a woman ought to be an angel-or she is an ass - for I discern not a trace of the human character, neither reason nor passion in this domestic drudge, whose being is absorbed in that of a tyrant's." (Wollstonecraft, 1993:178)

8. In "Revolutionary and Romantic Feminism" Kelly argues that by allotting women such an important and decisive role in national and international survival, More "has subverted the hierarchy of patriarchy by inverting it or by turning its inside (subjectivity, domesticity) out (the social, the public)" (Kelly, 1990: 118).

9. In The Family, Sex and Marriage in England 1500-1800 Lawrence Stone (1990) explains in detail the reasons for this double standard, one of them being of practical order: it was the only way to be sure about the legitimacy of the heir.

10. Of course, some women, such as Hays, Wollstonecraft or Mary Robinson, inveighed against the double standard of morality, pointing out the contradictions implicit in it: women were considered to be weak of intellect and reason, but a higher standard of behaviour was expected from them, whereas men, the rational and superior creatures, had no duty to virtue and good morals.

11. See Todd (1989), Anderson (2002), Brophy (1991), or Skinner (2000).

12. It is interesting to compare Berrendale's speech with this fragment from a letter by an eighteenth-century woman to a friend whose husband is a drunkard: "Pardon me if I should tell you you may in a great degree contribute to the misfortune you complain of by unamiableness of behaviour either sullen or sour, perhaps clamourous, which no man will bear from his mate that's vowed obedience and to love and to cherish.” (In Brophy, 1991: 149)

13. In relationship to Berrendale's infidelity Carol Howard has argued that "Paternalism, in fact, appears at its worst in Adeline Mowbray when it is most in conflict with domestic maternal authority, that is, when the cruelty and selfishness of the bad plantocrat husband links the feverish consumption of luxury foods to sexual predation in the household." (Howard, 1998: 363)

14. See Rogers (1982), Todd (1989), Cheryl Turner (1992), Mellor (1992), Spacks (1994), Forbes (1995), or Hoeveler (1998). Particularly interesting is Mellor's analysis of the commitment of Wollstonecraft, Helen Maria Williams and Mary Shelley to a political ideology based on the model of the egalitarian bourgeois family. Mellor argues that such a model not only promotes a new hierarchy based on age and ordinal position, but by emphasising sameness forces every individual to conform to an abstract norm.

15. In Becoming a Heroine. Reading about Women in Novels Rachel M. Brownstein (1992) argues that the ideology of companionate marriage and its emphasis on the fact that both parties must know each other beforehand if they want married life to be the most happy situation was just a fiction. Charlotte expresses it very clearly in Pride and Prejudice when she says that happiness in marriage is a matter of chance. Jane Austen knew very well that her endings were all quite unlikely and that finding the right man was most of the times just a dream.

16. Interestingly enough, in An Enquiry Concerning Political Justice Godwin introduces an appendix, "OfDuelling", where he acknowledges that a man who refuses duelling might be risking his reputation for courage and personal honour. Godwin defends that real courage is the courage to always tell the truth.

17. This is certainly a reference to Godwin, for whom marriage was the worst of monopolies: "So long as I seek, by despotic and artificial means, to maintain my possession of a woman, I am guilty of the most odious selfishness." (Godwin, 1976: 762)

18. We have to bear in mind that Adeline Mowbray is supposed to be a roman à clef about 
Wollstonecraft and Godwin.

19. I disagree with Eberle when she says that Adeline has been seduced by male language, because this would imply diminishing her capacity for intellectual and rational thought.

20. King and Pierce (1999) have pointed out how that even when Glenmurray refuses Major Douglas's challenge to a duel and thus betrays the code of honour, the consequences are really negligible for him: he never loses his reputation and social position.

21. In Women Writing about Money. Women's Fiction in England, 1790-1820 Copeland explains that when prostitution is brought into the woman's novel, it is presented as "an intentionally shocking emblem of the general, humiliating economic condition of Everywoman. It is an old tradition in women's fiction. The oldest profession becomes the woman novelist's whipping-post to expose an unjust society." (Copeland, 1996: 186).

22. Although Eberle (1994) agrees with Howard (1998) that this community of women seems to be Opie's solution to inherently flawed heterosexual unions, she doubts whether it is a good alternative, since it only helps to widen the gap between the private and the public spheres.

23. In "The Cult of Womanhood in Eighteenth-Century Thought" Marlene Legates explains the reasons for this cult of the virtuous woman that takes place in the age of the Enlightenment: "The new image of Womanhood was an attempt on the part of the upper classes to consolidate their precariously won prosperity and security against the 'outs' of society. But, in keeping with Enlightenment thought, the contribution of woman to humanity and to social exclusivity was a potential only, which needed guidance to be realized. Without men, women would not be amiable, declared Addison and Steele." (Legates, 1976: 38-39)

24. Compare this fragment with that other from Fordyce's Sermons to Young Women: "that they represent vices as frailties, and frailties as virtues; that they engender notions of love unspeakably perverting and inflammatory; that they overlook in a great measure the finest part of the passion, which one would suspect the authors had never experienced; that they turn it most commonly into an affair of wicked or of frivolous gallantry; that on many occasions they take off from the worst crimes committed in the prosecution of it, the horror which ought ever to follow them; on some occasions actually reward those very crimes, and almost on all leave the female readers with this persuasion at best, that it is their business to get husbands at any rate, and by whatever means?" (Fordyce, 1991: 178)

25. In "Discharging Debts: The Moral Economy of Amelia Opie's Fiction" Gary Kelly explains that Opie's tales are all based on a similar pattern - the incurring, recognition and discharging of debts of different kinds - and that the "balancing of accounts is frequently symbolized by death." (Kelly, 1980: 201). In "British Seduced Maidens" Susan Staves (1980-81) also points out that the fate of most seduced women in the novels of the late eighteenth and early nineteenth century is that of death.

26. On Savanna's subversive character and her assimilation within the discourse of sentimental abolitionism, see Eberle (1994) and Howard (1998).

\section{References}

Anderson, Misty G. (2002): Female Playwrights and Eighteenth-Century Comedy. Negotiating Marriage on the London Stage. New York: Palgrave.

Armstrong, Nancy (1989): Desire and Domestic Fiction. A Political History of the Novel. New York \& Oxford: Oxford University Press.

Backscheider, Paula R. (1987): “'I Died for Love': Esteem in Eighteenth-Century Novels by Women”. In Mary Anne Schofield and Cecilia Macheski, eds., Fetter'd or Free? British Women Novelists, 1670-1815. Athens, Ohio \& London: Ohio University Press, 152-168. 
Brightwell, Cecilia Lucy (1854): Memorials of the Life of Amelia Opie, Selected and Arranged from her Letters, Diaries, and Other Manuscripts. London: Longman \& Brown, \& Coo.

Brophy, Elizabeth Bergen (1991): Women's Lives and the $18^{\text {th }}$ Century English Novel. Tampa: University of South Florida Press.

Brownstein Rachel M., (1982): Becoming a Heroine. Reading about Women in Novels. New York: Columbia University Press.

Copeland, Edward (1996): Women Writing about Money. Women's Fiction in England, 1790-1820. Cambridge: Cambridge University Press.

Eberle, Roxanne (Summer 1994): “Amelia Opie's Adeline Mowbray: Diverting the Libertine Gaze; or, The Vindication of a Fallen Woman”. Studies in the Novel 26(2): 121-152.

Ferris, Ina (1991): The Achievement of Literary Authority: Gender, History, and the Waverley Novels. Ithaca \& London: Cornell University Press.

Fordyce, James (1991): Sermons to Young Women. In Vivien Jones, ed., Women in the Eighteenth Century: Constructions of Femininity. London \& New York: Routledge, 176-179.

Forbes, Joan (1995): “Anti-Romantic Discourse as Resistance: Women's Fiction 1775-1820”. In Jackie Stacey and Lynne Pearce, eds., Romance Revisited. New York: New York, 293-305.

Godwin, William (1976): An Enquiry Concerning Political Justice. Harmondsworth: Penguin.

Green, Katherine Sobba (1991): The Courtship Novel, 1740-1820. A Feminized Genre. Kentucky: The University Press of Kentucky.

Gregory, John (1991): A Father's Legacy to His Daughters, in Women in the Eighteenth Century. In Vivien Jones, ed., Women in the Eighteenth Century: Constructions of Femininity. London \& New York: Routledge, 44-53.

Hamilton, Elizabeth (1813): A Series of Popular Essays, Illustrative of Principles Essentially Connected with the Improvement of the Understanding, the Imagination, and the Heart, vol. II. Edinburgh: Longman.

Hays, Mary (1991): Appeal to the Men of Great Britain in behalf of the Women, in Women in the Eighteenth Century. In Vivien Jones, ed., Women in the Eighteenth Century: Constructions of Femininity. London \& New York: Routledge, 231-237.

Hoeveler, Diane Long (1998): Gothic Feminism. The Professionalization of Gender from Charlotte Smith to the Brontës. University Park, Pennsylvania: The Pennsylvania State University Press.

Howard, Carol (Fall 1998): "The Story of the Pineapple': Sentimental Abolitionism and Moral Motherhood in Amelia Opie's Adeline Mowbray". Studies in the Novel 30(3): 354-376.

Johnson, Claudia L. (1990): Jane Austen. Women Politics and the Novel. Chicago \& London: The University of Chicago Press.

Kelly, Gary (October 1980): "Discharging Debts: The Moral Economy of Amelia Opie's Fiction". The Wordsworth Circle 11: 198-203.

. (October 1981): “Amelia Opie, Lady Caroline Lamb, and Maria Edgeworth: Official and Unofficial Ideology". Ariel 12(4): 3-24.

. (1990): "Revolutionary and Romantic Feminism: Women, Writing, and Cultural Revolution”. In Keith Hanley and Raman Selden, eds., Revolution and English Romanticism: Politics and Rhetoric. Hemel Hempstead: St. Martin's Press, 107-130.

. (1997): Women, Writing, and Revolution 1790-1827. Oxford: Clarendon Press.

King, Shelley and John B. Pierce (eds.) (1999): Adeline Mowbray; or, The Mother and Daughter. Oxford: Oxford University Press. . (eds.) (2003): The Father and Daughter with Dangers of Coquetry. Toronto: Broadview Press. 
Legates, Marlene (1976): "The Cult of Womanhood in Eighteenth-Century Thought". EighteenthCentury Studies 10: 21-39.

Macaulay, Catherine (1991): Letters on Education, in Women in the Eighteenth Century. In Vivien Jones, ed., Women in the Eighteenth Century: Constructions of Femininity. London \& New York: Routledge, 112-116.

Mellor, Anne K. (1992): "English Women Writers and the French Revolution". In Sara E. Melzer \& Leslie W. Rabine, eds., Rebel Daughters: Women and the French Revolution. Oxford: Oxford University Press, 255-272.

More, Hannah (1991): "Strictures on the Modern System of Female Education." In Vivien Jones, ed., Women in the Eighteenth Century: Constructions of Femininity. London \& New York: Routledge, 131-139. . (2003): "Strictures on the Modern System of Female Education." In Amelia Opie, The Father and Daughter with Dangers of Coquetry, Shelley King and John B. Pierce, eds., Toronto: Broadview Press, 326-329.

Newton, Judith Lowder (1981): Women, Power and Subversion. Social Strategies in British Fiction: 1778-1860. Athens: The University of Georgia Press.

Opie, Amelia (1999): Adeline Mowbray; or, The Mother and Daughter. Shelley King and John B. Pierce, eds. Oxford: Oxford University Press.

Pennington, Lady Sarah (1966): An Unfortunate Mother's Advice to Her Absent Daughters. In Frank W. Bradbrook, Jane Austen and Her Predecessors. Cambridge: Cambridge University Press, 143-154.

Perry, Ruth (February 1992): "Colonizing the Breast: Sexuality and Maternity in Eighteenth-Century England”. Eighteenth-Century Life 16: 185-213.

Polwhele, Richard (1991): The Unsex'd Females: A Poem. In Vivien Jones, ed., Women in the Eighteenth Century: Constructions of Femininity. London \& New York: Routledge, 186-191.

Rogers Katharine M. (1982): Feminism in Eighteenth-Century England (Urbana \& Chicago: University of Illinois Press.

Salignac de la Mothe-Fénélon, François de (1991): Treatise on the Education of Daughters, in Women in the Eighteenth Century. In Vivien Jones, ed., Women in the Eighteenth Century: Constructions of Femininity. London \& New York: Routledge, 102-104.

Savile, George, Marquis of Halifax (1991): The Lady's New Year's Gift: or, Advice to a Daughter. In Vivien Jones, ed., Women in the Eighteenth Century: Constructions of Femininity. London \& New York: Routledge, 17-22.

Skinner, Gillian (2000): "Women's Status as Legal and Civic Subjects: 'A Worse Condition than Slavery Itself?"”. In Vivien Jones, ed., Women and Literature in Britain, 1700-1800. Cambridge: Cambridge University Press, 91-110.

Spacks, Patricia Meyer (1994): Desire and Truth. Functions of Plot in Eighteenth-Century Novels. Chicago \& London: The University of Chicago Press.

Staves, Susan (1980-81): "British Seduced Maidens". Eighteenth-Century Studies 12: 109-34.

Stone, Lawrence (1990): The Family, Sex and Marriage in England 1500-1800, Harmondsworth: Penguin.

The Hardships of the English Laws in Relation to Wives, in Women in the Eighteenth Century. In Vivien Jones (1991), ed., Women in the Eighteenth Century: Constructions of Femininity. London \& New York: Routledge, 217-225.

Todd, Janet (1989): The Sign of Angellica: Women, Writing and Fiction, 1660-1800. New York: Columbia University Press. 
Turner, Cheryl(1992): Living by the Pen. Women Writers in the Eighteenth Century. London \& New York: Routledge.

Ty, Eleanor (1994): "Mary Hays". In Steven Serafin, ed., Dictionary of Literary Biography 142: Eighteenth-Century British Literary Biographers. Detroit: Bruccoli Clark Layman, 152-160. . (1998): Empowering the Feminine: The Narratives of Mary Robinson, Jane West, and Amelia Opie, 1796-1812. Toronto, Buffalo \& London: University of Toronto Press.

Wikborg, Eleanor (2002): The Lover as Father Figure in Eighteenth-Century Women's Fiction. Gainesville: University Press of Florida.

Wilkes, Wetenhall (1991): A Letter of Genteel and Moral Advice to a Young Lady, in Women in the Eighteenth Century. In Vivien Jones, ed., Women in the Eighteenth Century: Constructions of Femininity. London \& New York: Routledge, 29-35.

Wollstonecraft, Mary (1993): A Vindication of the Rights of Woman. In Janet Todd, ed., Political Writings. Toronto \& Buffalo: University of Toronto Press.

Zimmerman, Sarah (1991): "Charlotte Smith's Letters and the Practice of Self-Presentation". Princeton University Library Chronicle, 53(1): 50-77. 